\title{
Noise and Infrasonic Noise at Workplaces in a Wind Farm
}

\author{
Dariusz PLEBAN, Jan RADOSZ, Bożena SMAGOWSKA \\ Central Institute for Labour Protection - National Research Institute \\ Czerniakowska 16, 00-701 Warszawa, Poland; e-mail: daple@ciop.pl
}

(received March 7, 2017; accepted March 20, 2017)

\begin{abstract}
Dynamic development of wind power should take into account requirements resulting from environmental protection and human health. However in the case of occupational exposure to noise emitted by wind turbines (workplaces of wind turbine operation personnel, including persons performing maintenance) there are no documented data in literature in this regard. An example of pilot assessments of noise and infrasonic noise at workplaces in a wind farm is presented in the paper. The results of measurements and assessments of noise emitted by the wind turbines Vestas V80-2.0 MW show that noise does not constitute health hazard for wind farm workers. Furthermore infrasonic noise emitted by the wind turbines Vestas V80-2.0 MW is not an annoyance agent for wind farm workers.
\end{abstract}

Keywords: wind turbine noise; infrasonic noise; occupational exposure.

\section{Introduction}

In the European Union the necessity to develop renewable power generation, including wind power, results inter alia from the provisions of the Directive $2009 / 28 / \mathrm{EC}$ on the promotion of the use of energy from renewable sources (Directive 2009/28/EC, 2009). General goals of the Directive assume reaching $20 \%$ of final gross energy consumption in 2020 within the Community coming from renewable sources. Poland has to achieve a $15 \%$ share of energy from renewable sources in 2020. Renewable sources of energy are minor but growing sources of electrical energy and thermal energy in Poland. The share of energy from renewable sources in final consumption of energy was $11.45 \%$ in 2014 (BERENT-KowALSKA et al., 2015). By way of comparison, in the European Union the share of renewable energy in gross final energy consumption was $14.1 \%$ in 2013 (Eurostat, 2015). For these reasons, the generation of electrical energy from wind is priority for the European Union and Poland.

Wind turbines and wind farms are relatively new addition to the Polish landscape. Wind turbines on a commercial scale are a modern phenomenon. The first wind turbine was installed in Poland (in Lisewo) in 1991 (LEWANDOWsKI, 2012), while the first wind farm was started in Poland ten years later (in 2001), with the total installed capacity $10 \mathrm{MW}$ (Wind power in Poland, 2017).
Although many people are involved in wind energy development, some people have become concerned about possible impacts to their quality of life and the quality of environment - as reported in literature (Stryjecki, Mielniczak, 2011; PaWlas et al., 2012; FORTIN et al., 2013) the impact of wind farms during their operation can be brought down to their impact on: avifauna and chiropteran fauna, acoustic climate of the environment (noise and infrasonic emissions), electromagnetic climate of the environment, optical phenomena, landscape, failures and accidents, value of property.

There is a number of publications relating to the environmental and health impact of wind turbine noise (e.g.: Rubin et al., 2014; Magari et al., 2014). As shown by the studies (PAWlas et al., 2012; ForTin et al., 2013), typical infrasonic noise levels (G-weighted sound pressure levels), measured about $100 \mathrm{~m}$ from the wind turbines fall within the range of 50 to $70 \mathrm{~dB}(\mathrm{G})$ and are significantly below the infrasound threshold of hearing. Studies carried out in Sweden and the Netherlands have shown that a dose-response relation between A-weighted sound pressure levels in $\mathrm{dB}(\mathrm{A})$, sound perception and annoyance exists (PEDERSEN, Persson Waye, 2004; Pedersen et al., 2009). In the epidemiological studies Pedersen and Persson WAYE (2007) have shown that annoyance resulting from a wind turbine noise occurs even at $\mathrm{A}$-weighted sound pressure level of $32.5 \mathrm{~dB}(\mathrm{~A})$. 
The report prepared by the Expert Panel on Wind Turbine Noise and Human Health has found sufficient evidence that exposure to wind turbine noise (possibly in combination with other factors) can contribute to annoyance, and that such exposure does not lead to hearing loss (Council of Canadian Academies, 2015). The results of the Canadian epidemiology study showed among others: the levels of infrasound were around the threshold of audibility, a statistically significant increase in annoyance was found when wind turbine noise level exceeded $35 \mathrm{~dB}(\mathrm{~A})$, self-reported illnesses and chronic diseases were not found to be associated with exposure to wind turbine noise levels (Health Canada, 2014; Michaud, 2015; MiCHAUd et al., 2016a; 2016b; 2016c; VoICESCU et al., 2016).

Polish studies by MroczeK et al. (2012; 2013) have shown that subjective assessment of quality of life for persons exposed to wind farm-generated noise depends on personality, and the noise is not seen as a factor that may impair the health condition. The results of the questionnaire inquiry on response to wind turbine noise (PAWLACZYK-ŁUSZCZYŃSKA et al., 2014), carried out on 361 subjects living in the vicinity of wind farms, showed that generally, $33 \%$ of respondents were annoyed outdoors by wind turbine noise while indoors the noise was annoying to $21.3 \%$ of them.

However in the case of occupational exposure to noise and infrasonic noise emitted by wind turbines (workplaces of turbine operation personnel, including persons performing maintenance and repairs), there are no documented data in literature in this regard. The development of the wind energy sector in Poland is accompanied by an increase in the number of people employed in job positions associated with wind energy. In 2014, a total of 8400 people worked in the wind energy sector in Poland, of which 600 people were employed directly for the operation of the existing wind farms (compared to 300 people employed for this purpose in 2005) (Bukowski, ŚNIEGOCKI, 2015). For this reason, the aim of the pilot study was to carry out assessment related to occupational exposure to noise and infrasonic noise at workplaces in a wind farm.

\section{Materials and methods}

\subsection{Tested wind farm}

At the end of January 2017 in Poland a total of 666 wind turbines manufactured by 9 various companies were installed at 40 wind farms with a capacity of more than $5 \mathrm{MW}$ each (Wind power in Poland, 2017). Among these manufacturers, the leader is Vestas, whose 208 wind turbines were operated at 16 wind farms, with nearly $37 \%$ of these turbines ( 77 wind turbines) being of the Vestas V80-2.0 MW type. Therefore, for the purposes of the study, the tested objects were Vestas V80-2.0 MW type wind turbines.
The characteristic technical parameters of the tested Vestas V80-2.0 MW wind turbines were following (Vestas V80, n.d.):

- rated power: $2 \mathrm{MW}$,

- rotor diameter: $80 \mathrm{~m}$,

- tower height: $100 \mathrm{~m}$.

The measurements of noise and infrasonic noise were carried out at workplaces in a wind farm located in West Pomeranian Voivodship (north-west part of Poland). The farm included 25 Vestas V80-2.0 MW wind turbines. The wind turbines were located about $450 \mathrm{~m}$ from each other.

\subsection{Test methods and equipment used for measurements}

The scope of noise measurements at workplaces in the wind farm included the determination of the following noise parameters: the A-weighted noise exposure level normalized to an 8-hour working day (the daily noise exposure level) $\left(L_{\mathrm{AEx}, 8 \mathrm{~h}}\right)$, the maximum $\mathrm{A}$-weighted sound pressure level $\left(L_{\mathrm{A} \max }\right)$ and the C-weighted peak sound pressure level $\left(L_{\text {Cpeak }}\right)$. According to the Polish regulation on health and safety at work related to exposure to noise and vibration (Minister of Economy and Labour, 2005) the knowledge of the values of these parameters is necessary for the noise exposure assessment. Noise measurements were carried out in accordance with the European Standard EN ISO 9612 (2009).

For the purpose of noise assessment the values of measured sound pressure levels were compared with the admissible values. According to the Polish regulation on maximum concentrations and intensities of harmful factors in working conditions (Minister of Labour and Social Policy, 2014) admissible values of quantities of noise (maximum allowable intensities (MAI) for noise) are following: the daily noise exposure level $L_{\mathrm{AEx}, 8 \mathrm{~h}}=85 \mathrm{~dB}(\mathrm{~A})$ (or the weekly noise exposure level $\left.L_{\mathrm{AEx}, \mathrm{w}}=85 \mathrm{~dB}(\mathrm{~A})\right)$, the maximum A-weighted sound pressure level $L_{\mathrm{A} \max }=115 \mathrm{~dB}(\mathrm{~A})$, the $\mathrm{C}$-weighted peak sound pressure level $L_{\text {Cpeak }}=$ $135 \mathrm{~dB}(\mathrm{C})$.

However, the scope of infrasonic noise measurements included the determination of the equivalent G-weighted sound pressure levels. The measurements were carried out in accordance with the European Standard EN ISO 9612 and the Polish Standard PN-Z01338 (2010). There are no values of MAI for infrasonic noise in Polish law, but there is a non-obligatory annoyance criterion specified in the above mentioned Polish Standard PN-Z-01338. According to this Standard the values of the infrasonic noise annoyance criterion are following:

- the G-weighted equivalent sound pressure level, normalised to a nominal 8-hour working day or 
the 40-hour average weekly working time for all employees $L_{\mathrm{Geq}, 8 \mathrm{~h}}\left(\right.$ or $\left.L_{\mathrm{Geq}, \mathrm{w}}\right)=102 \mathrm{~dB}(\mathrm{G})$,

- the G-weighted equivalent sound pressure level, during occupation of a workplace designated for conceptual work $L_{\mathrm{Geq}}=86 \mathrm{~dB}(\mathrm{G})$.

Measurements of noise and infrasonic noise were taken using sound analysers SVAN 945 and SVAN 979 with preamplifiers SV11, SV01A and SV17, microphones $40 \mathrm{AN}$ (G.R.A.S.) and $40 \mathrm{AE}$ (G.R.A.S.), personal noise dose meters B\&K 4448 with microphones B\&K 39004 and 36963.

\section{Description of measurements}

This has been referred to earlier - the aim of the pilot study was to carry out noise and infrasonic noise assessments at workplaces in the wind farm. Therefore the scope of works carried out included:

- an analysis of work being carried out by the personnel operating wind farms,

- measurements of noise and infrasonic noise,

- determination of the noise and the infrasonic noise occupational exposure.

Measurements of noise and infrasonic noise were carried out during the performance of service support and maintenance activities by employees on 6 wind turbines and at the transformer station. An important facility at the tested wind farm is the transformer station area where, inter alia, a storage area, a room for mental and administrative work, and employee lounges are located.

Based on the characteristics of work associated with the service support and operation of the wind turbine, the most representative (most common) activities were selected, for which the measurements of noise and infrasonic noise were carried out. The selected activities included:

- loading work within the transformer station area, associated with loading necessary tools and materials into the car,

- driving a car in order to get from the transformer station to a wind turbine, moving between turbines, and the return journey to the transformer station,

- unloading of tools and materials near a wind turbine,

- loading of tools in a wind turbine,

- going up in a lift in order to reach the nacelle, and going down,

- hoisting tools and materials to the nacelle,

- maintenance work in the nacelle,

- diagnostic work in the nacelle - checking on oil cooler engines,
- diagnostic work in the nacelle - checking on generator fans,

- service support activities in the nacelle - lubrication of turbine blade bearings,

- service support activities in the nacelle - lubrication of the main shaft bearings,

- simulation of the operation of all devices in the nacelle,

- tightening screws on mechanical elements inside the turbine,

- repair of a turbine failure,

- mental and administrative work performed within the transformer station area.

Given the wide diversity of activities performed by employees operating wind turbines, a task based measurements strategy (EN ISO 9612) was selected. However, it might not always be employed. Given the specificity of working conditions of these employees, including:

- restricted working space inside a wind turbine nacelle,

- restricted space and limited access to the interior of the wind turbine tower,

- the need for meeting the requirements related to the working at heights $(100 \mathrm{~m})$ as well as electrical and mechanical hazards inside the wind turbine nacelle,

it was necessary to employ also a full-day measurements strategy (EN ISO 9612).

Where acoustic measurements were carried out outside i.e. in an open space, the recorded weather conditions in the places where measurement microphones were located were as follows:

- air temperature: $6-10^{\circ} \mathrm{C}$,

- air humidity: 55-58\%,

- atmospheric pressure: $1,023-1,023.5 \mathrm{hPa}$,

- wind speed: $5.7-8.1 \mathrm{~m} / \mathrm{s}$.

\section{Results and discussion}

Noise and infrasonic noise measurements were carried out for each of the above-listed activities performed by employees operating the tested wind farm. The measurement results are given in Table 1. Beyond that, the exemplary spectres of noise at the selected workplaces are presented in Figs. 1-5.

An analysis of the measurement data indicates that, as regards the noise accompanying the activities performed inside a wind turbine, the highest sound pressure levels occur in $1 / 3$ octave bands with centre frequencies of up to $10 \mathrm{~Hz}$. Moreover, the noise is dominated by low frequencies of up to $500 \mathrm{~Hz}$. Also for the noise occurring in the room for conceptual and admini- 
Table 1. Results of the measurements of noise and infrasonic noise carried out during the performance of operations involving the service support and maintenance of wind turbines.

\begin{tabular}{|c|c|c|c|c|}
\hline Activity & $\begin{array}{c}L_{\text {Aeq }} \\
{[\mathrm{dB}(\mathrm{A})]}\end{array}$ & $\begin{array}{c}L_{\mathrm{A} \max } \\
{[\mathrm{dB}(\mathrm{A})]}\end{array}$ & $\begin{array}{c}L_{\text {Cpeak }} \\
{[\mathrm{dB}(\mathrm{C})]}\end{array}$ & $\begin{array}{c}L_{\mathrm{Geq}} \\
{[\mathrm{dB}(\mathrm{G})]}\end{array}$ \\
\hline Loading work within the transformer station area & 40.2 & 41.4 & 75.2 & 71.5 \\
\hline Driving a car & 67.6 & 74.5 & 113.4 & 102.4 \\
\hline Unloading of tools and materials & 48.5 & 50.4 & 79.5 & 76.3 \\
\hline Going up in a lift & 80.4 & 80.8 & 103.1 & 84.3 \\
\hline Loading of tools in a wind turbine & 64.0 & 69.9 & 92.0 & 83.3 \\
\hline Hoisting tools and materials to the nacelle & 71.8 & 73.1 & 94.3 & 71.7 \\
\hline Maintenance work in the nacelle & 72.6 & 74.5 & 91.5 & 74.6 \\
\hline Diagnostic work in the nacelle - checking on oil cooler engines & 90.7 & 90.9 & 105.7 & 87.5 \\
\hline Diagnostic work in the nacelle - checking on generator fans & 80.3 & 86.9 & 107.5 & 82.8 \\
\hline Service support activities in the nacelle - lubrication of turbine blade bearings & 79.6 & 87.2 & 97.1 & 74.1 \\
\hline Service support activities in the nacelle - lubrication of the main shaft bearings & 75.6 & 78.0 & 95.7 & 76.5 \\
\hline Simulation of the operation of all devices in the nacelle & 92.5 & 93.0 & 108.3 & 91.5 \\
\hline Tightening screws on mechanical elements inside the turbine & 83.3 & 97.0 & 113.4 & 93.4 \\
\hline Repair of a turbine failure & 76.0 & 93.9 & 126.2 & 93.4 \\
\hline Mental and administrative work performed within the transformer station area & 40.2 & 41.4 & 75.2 & 71.5 \\
\hline
\end{tabular}

$L_{\text {Aeq }}$ - the A-weighted equivalent sound pressure level,

$L_{\mathrm{A} \max }$ - the maximum A-weighted sound pressure level,

$L_{\text {Cpeak }}$ - the C-weighted peak sound pressure level,

$L_{\mathrm{Geq}}$ - the G-weighted equivalent sound pressure level.

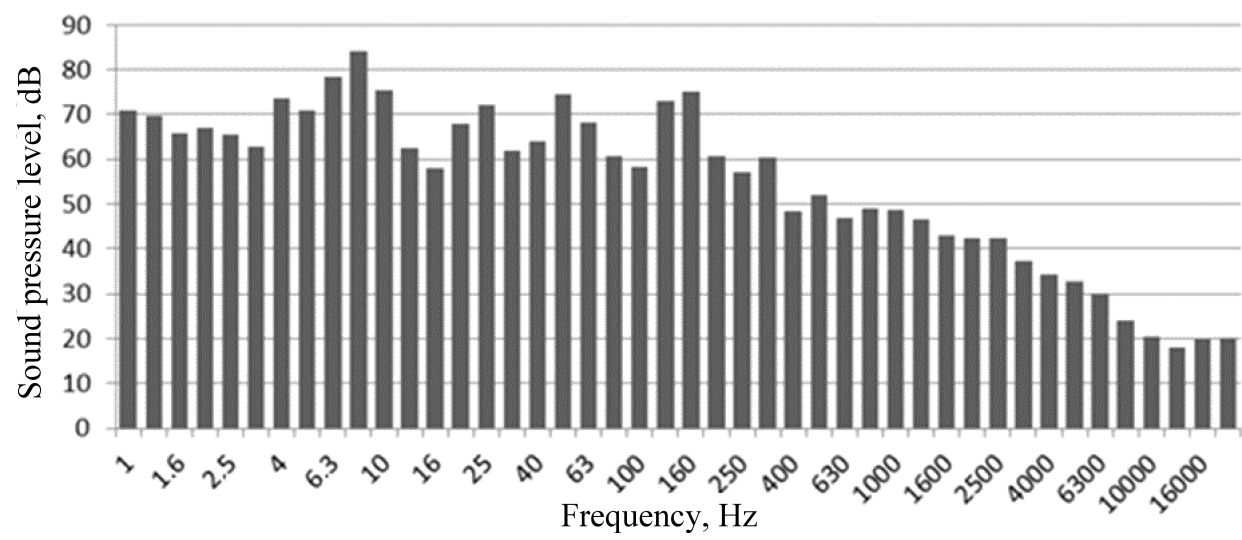

Fig. 1. Spectrum of the noise during loading of tools in a wind turbine.

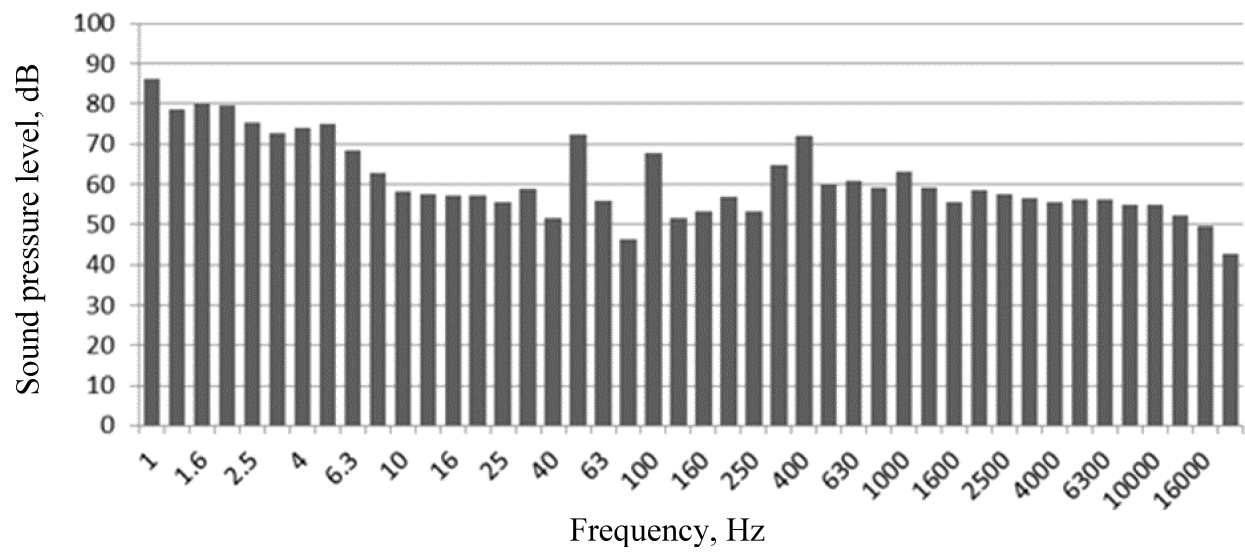

Fig. 2. Spectrum of the noise during hoisting tools and materials to the nacelle. 


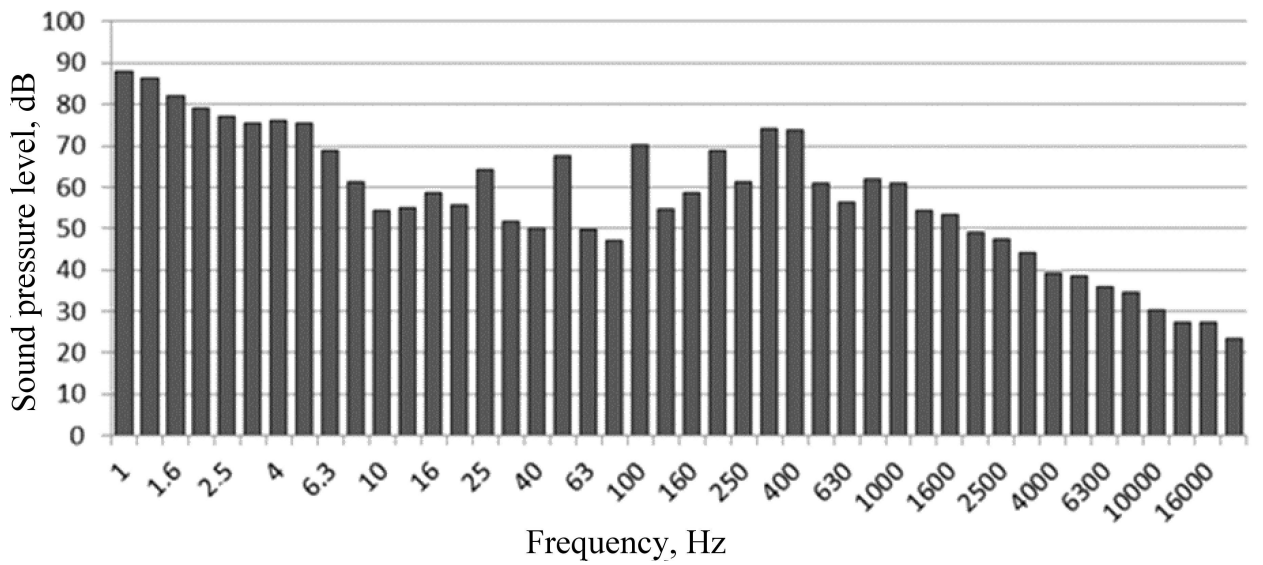

Fig. 3. Spectrum of the noise during maintenance work in the nacelle.

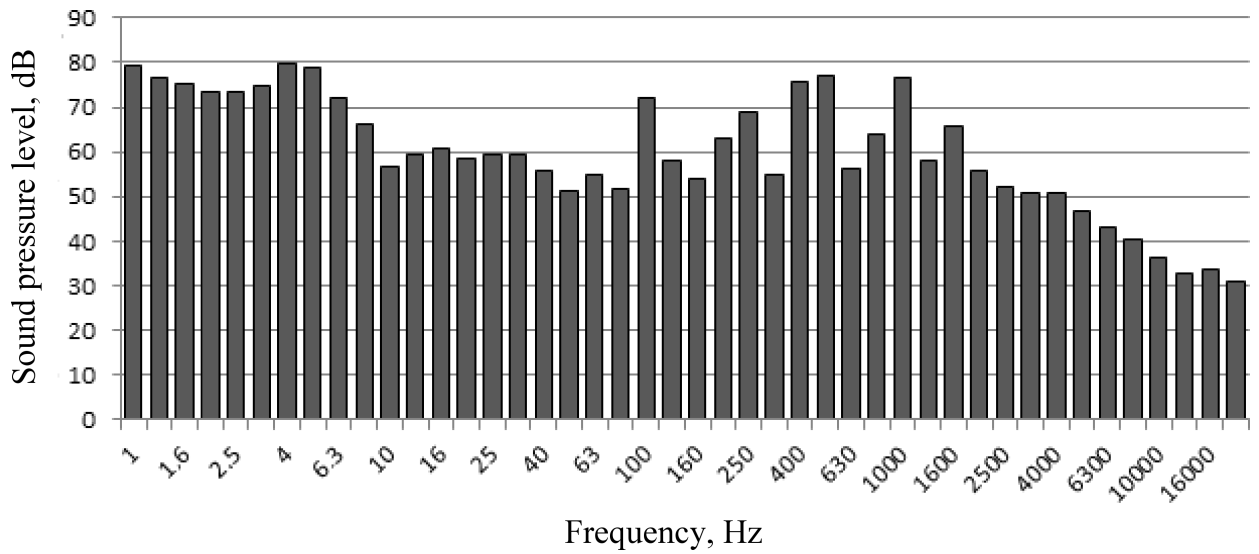

Fig. 4. Spectrum of the noise during service support activities in the nacelle - lubrication of turbine blade bearings.

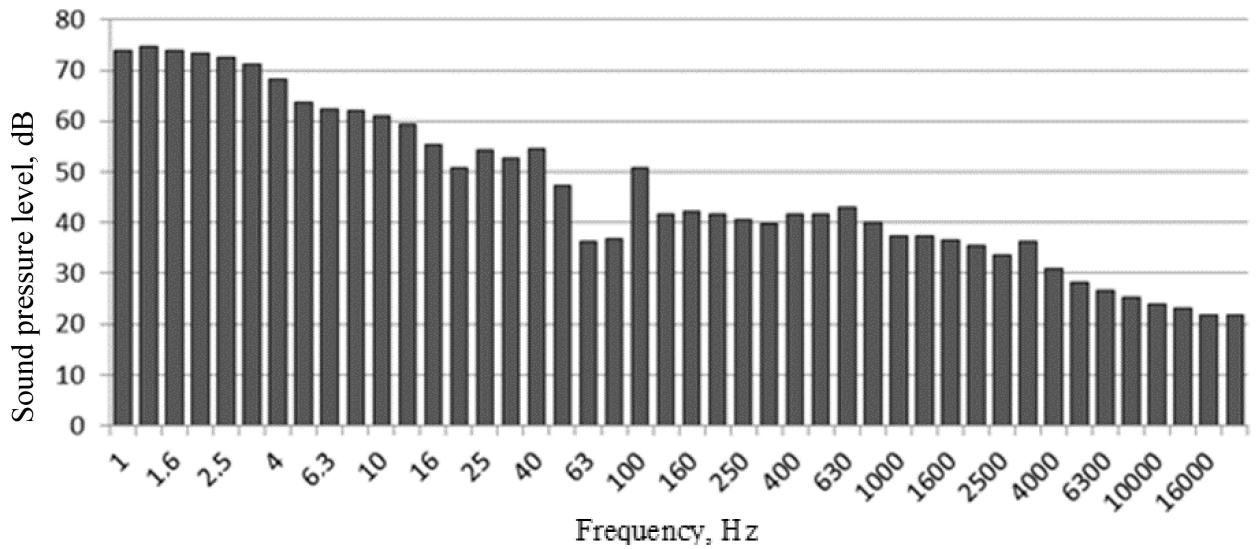

Fig. 5. Spectrum of the noise during mental and administrative work.

strative work (in a welfare unit within the transformer station area, located $750 \mathrm{~m}$ away from the nearest operating wind turbine), the highest sound pressure levels occur within the frequency range of up to $10 \mathrm{~Hz}$, with low frequencies of up to $50 \mathrm{~Hz}$ dominating in the spectrum.

A comparison of the results provided in Table 1 shows that:

- only during the work involving the simulation of the operation of all devices and diagnostic work involving the checking on oil cooler engines, the measured A-weighted equivalent sound pressure levels exceeded the MAI value $(85 \mathrm{~dB}(\mathrm{~A}))$ and amounted to 92.5 and $90.7 \mathrm{~dB}(\mathrm{~A})$, respectively,

- the measured maximum A-weighted sound pressure levels did not exceed the MAI value equal to $115 \mathrm{~dB}(\mathrm{~A})$ during any of the activities involving the service support and operation of wind turbines - the highest measured value was $97 \mathrm{~dB}(\mathrm{~A})$ during tightening screws, 
- the measured $\mathrm{C}$-weighted peak sound pressure levels did not exceed the MAI value equal to $135 \mathrm{~dB}(\mathrm{C})$ during any of the activities involving the service support and operation of wind turbines - the highest measured value was $126.2 \mathrm{~dB}(\mathrm{C})$ during the work involving the repair of a failure,

- only during the moving by car within the wind farm area, the measured G-weighted equivalent sound pressure levels exceeded a criterial value (infrasonic noise annoyance criterion) equal to $102 \mathrm{~dB}(\mathrm{G})$ - the measured level was $102.4 \mathrm{~dB}(\mathrm{G})$.

In order to perform an assessment of the exposure of the personnel operating the wind farm to noise, it is necessary to determine the noise exposure level. As regards this category of employees, the noise affecting their bodies is non-uniform in nature on particulars days of the week. It was therefore necessary to determine the noise exposure level normalised to the average weekly working (the weekly noise exposure level), $L_{\mathrm{EX}, \mathrm{w}}$. To this end, a typical list of activities performed on every day of the week as well as their duration was specified by means of interviews carried out with employees servicing and operating wind farms. On this basis, and based on the noise measurement results, it was possible to prepare the data on the exposure of the personnel operating wind farms to noise and infrasonic noise on particular days of the week and then the weekly noise exposure levels. These data are listed in Table 2.

The data listed in Table 2 indicate that the determined values describing the noise and the infrasonic noise are different on particular days of the week, depending on the activities performed, i.e.:
- the daily noise exposure levels (normalised to nominal 8-hour working day) change from $39.9 \mathrm{~dB}$ to $83 \mathrm{~dB}(\mathrm{~A})$,

- the daily maximum A-weighted maximum sound pressure levels have values from $41.4 \mathrm{~dB}$ to $97 \mathrm{~dB}(\mathrm{~A})$,

- the daily $\mathrm{C}$-weighted peak sound pressure levels have values from $75.2 \mathrm{~dB}$ to $126.2 \mathrm{~dB}(\mathrm{C})$,

- the daily G-weighted equivalent sound pressure levels (normalised to an 8-hour working day) have values from $71.5 \mathrm{~dB}$ to $93.5 \mathrm{~dB}(\mathrm{G})$.

On none of the days of the week, the noise values within the audible frequency range, determined based on measurement results, exceeded the MAI values. The G-weighted equivalent sound pressure level of infrasonic noise did not exceed either in terms of the work annoyance criterion.

In addition, the determined weekly noise exposure levels and weekly sound pressure levels (see Table 2) should be assessed in relation to the MAI values of noise in the work environment, included in the Regulation of the Minister of Labour and Social Policy and in relation to the infrasonic noise annoyance criterion provided in the standard PN-Z-01338. The noise and infrasonic noise at tested workplaces do not exceed the MAI values and the value of infrasonic noise annoyance criterion, respectively:

- the determined weekly noise exposure level, $L_{\mathrm{AEx}, \mathrm{w}}=78.1 \mathrm{~dB}(\mathrm{~A})$, is lower by $6.9 \mathrm{~dB}(\mathrm{~A})$ than the MAI value equal to $85 \mathrm{~dB}(\mathrm{~A})$,

- the determined weekly maximum A-weighted sound pressure level, $L_{\mathrm{A} \max }=93.9 \mathrm{~dB}(\mathrm{~A})$, is lower by $21.1 \mathrm{~dB}(\mathrm{~A})$ than the MAI value equal to $115 \mathrm{~dB}(\mathrm{~A})$,

Table 2. Exposure to noise at workplaces of employees operating wind turbines on particular days of the week and weekly noise exposure level.

\begin{tabular}{|c|c|c|c|c|c|c|c|c|}
\hline Day of the week & $\begin{array}{l}L_{\mathrm{AEx}, 8 \mathrm{~h}} \\
{[\mathrm{~dB}(\mathrm{~A})]}\end{array}$ & $\begin{array}{l}L_{\mathrm{AEx}, \mathrm{w}} \\
{[\mathrm{dB}(\mathrm{A})]}\end{array}$ & $\begin{array}{c}L_{\mathrm{A} \max , 8 \mathrm{~h}} \\
{[\mathrm{~dB}(\mathrm{~A})]}\end{array}$ & $\begin{array}{c}L_{\mathrm{A} \max , \mathrm{w}} \\
{[\mathrm{dB}(\mathrm{A})]}\end{array}$ & $\begin{array}{c}L_{\text {Cpeak, } 8 \mathrm{~h}} \\
{[\mathrm{~dB}(\mathrm{C}])}\end{array}$ & $\begin{array}{c}L_{\text {Cpeak, w }} \\
{[\mathrm{dB}(\mathrm{C})]}\end{array}$ & $\begin{array}{l}L_{\mathrm{Geq}, 8 \mathrm{~h}} \\
{[\mathrm{~dB}(\mathrm{G})]}\end{array}$ & $\begin{array}{l}L_{\text {Geq, w }} \\
{[\mathrm{dB}(\mathrm{G})]}\end{array}$ \\
\hline 1 & 76.5 & \multirow{5}{*}{78.1} & 93.0 & \multirow{5}{*}{97.0} & 113.4 & \multirow{5}{*}{126.2} & 93.5 & \multirow{5}{*}{92.5} \\
\hline 2 & 76.2 & & 90.9 & & 113.4 & & 93.4 & \\
\hline 3 & 75.7 & & 93.9 & & 126.2 & & 93.4 & \\
\hline 4 & 83.0 & & 97.0 & & 113.4 & & 93.4 & \\
\hline 5 & 39.9 & & 41.4 & & 75.2 & & 71.5 & \\
\hline
\end{tabular}

$L_{\mathrm{AEx}, 8 \mathrm{~h}}$ - the daily A-weighted noise exposure level,

$L_{\mathrm{AEx}, \mathrm{w}}-$ the weekly noise exposure level,

$L_{\mathrm{A} \max , 8 \mathrm{~h}}$ - the daily maximum A-weighted sound pressure level,

$L_{\mathrm{A} \max , \mathrm{w}}$ - the weekly maximum A-weighted sound pressure level,

$L_{\text {Cpeak, } 8 \mathrm{~h}}$ - the daily C-weighted sound pressure level,

$L_{\text {Cpeak, w }}$ - the weekly C-weighted sound pressure level,

$L_{\mathrm{Geq}, 8 \mathrm{~h}}$ - the daily $\mathrm{G}$-weighted equivalent sound pressure level,

$L_{\text {Geq, w }}$ - the weekly G-weighted equivalent sound pressure level. 
- the determined weekly $\mathrm{C}$-weighted peak sound pressure level, $L_{\text {Cpeak }}=126.2 \mathrm{~dB}(\mathrm{C})$, is lower by $8.8 \mathrm{~dB}(\mathrm{C})$ than the MAI value equal to $135 \mathrm{~dB}(\mathrm{C})$,

- the determined weekly G-weighted equivalent sound pressure level, $L_{\text {Geq,w }}=92.5 \mathrm{~dB}(\mathrm{G})$, is lower by $9.5 \mathrm{~dB}(\mathrm{G})$ than the value of infrasonic noise annoyance criterion for all employees, which is $102 \mathrm{~dB}(\mathrm{G})$.

Having focused on one particular day of the working week (day number 5 of the week in Table 2) of a person operating wind farms i.e. when the person performs mental and administrative work indoors (the welfare unit located within the transformer station area), it may be concluded that:

- the determined A-weighted equivalent sound pressure level, $L_{\mathrm{AEx}, 8 \mathrm{~h}}=39.92 \mathrm{~dB}(\mathrm{~A})$ does not exceed the permissible level of noise in terms of the employee's opportunity to perform his basic tasks, which is equal to $55 \mathrm{~dB}(\mathrm{~A})$ in administrative rooms and rooms for theoretical work and data preparation (in accordance with the Polish Standard PN-N-01307 (1994)),

- the determined G-weighted equivalent sound pressure level, $L_{\mathrm{Geq}, 8 \mathrm{~h}}=71.5 \mathrm{~dB}(\mathrm{G})$ does not exceed the value being an infrasonic noise annoyance criterion at a work station for the performance of mental work, which is equal to $86 \mathrm{~dB}(\mathrm{G})$ (in accordance with Polish Standard PN-Z-01338).

\section{Conclusions}

On the basis of an analysis of the activities carried out by the wind farm staff and interviews with the employees, a typical weekly profile of work activities was developed. Thereafter, noise and infrasonic noise measurements at workplaces in the wind farm were carried out during service and maintenance activities carried out by the staff.

As the noise affecting the staff employees is nonuniform in nature on particular days of the week, noise exposure levels normalised to the average weekly working time, were determined in order to assess the noise and infrasonic noise exposure.

It was concluded, based on the study, that noise of the Vestas V80-2.0 MW wind turbines (for specific atmospheric conditions and turbines operating conditions) at workplaces in wind farms poses no threat to employees' health, because the noise exposure levels normalized to working week did not exceed the MAI value. The determined maximum A-weighted and $\mathrm{C}$-weighted peak sound pressure level normalized to working week did not exceed the MAI values.

The infrasonic noise likewise doesn't constitute the annoyance factor, as the G-weighted equivalent sound pressure level was below the criterial value.

\section{Acknowledgments}

This paper has been based on the results of a research task carried out within the scope of the third stage of the National Programme "Improvement of safety and working conditions" partly supported in 2014-2016 - within the scope of research and development - by the Ministry of Science and Higher Education/National Centre for Research and Development. The Central Institute for Labour Protection - National Research Institute was the Programme's main co-ordinator.

\section{References}

1. Berent-Kowalska G., Kacprowska J., Moskal I., JuRGAŚ A. (2015), Energy from renewable sources in 2014 [in Polish: Energia ze źódel odnawialnych w $2014 r$.], GUS, Warszawa.

2. Bukowski M., Śniegocki A. (2015), Wind energy impact on the Polish job market [in Polish: Wplyw energetyki wiatrowej na polski rynek pracy], WISE, Warszawa.

3. Council of Canadian Academies (2015), Understanding the evidence: wind turbine noise: The Expert Panel on Wind Turbine Noise and Human Health, Council of Canadian Academies, Ottawa.

4. Directive 2009/28/EC of the European Parliament and of the Council of 23 April 2009 on the promotion of the use of energy from renewable sources and amending and subsequently repealing Directives 2001/77/EC and 2003/30/EC, OJ L 140, 5.6.2009, 16-62.

5. EN ISO 9612:2009 Acoustics - Determination of occupational noise exposure - Engineering method.

6. Eurostat (2015), Eurostat Newsrelease 38/2015 March 2, 2015, Europe 2020 Strategy. How is the European Union processing towards its Europe 2020 targets?, Luxembourg.

7. Fortin P., Rideout K., Copes R., Bos C. (2013), Wind turbines and health, www.ncceh.ca/sites/default/files/Wind_Turbines_Feb_2013.pdf (retrieved February 14, 2017).

8. Health Canada (2014), Wind turbine noise and health study: summary and results, www.hc-sc.gc.ca/ ewhsemt/noise-bruit/turbine-eoliennes/summaryeng.php (retrieved February 14, 2017).

9. Lewandowski W.M. (2012), Proecological renewable energy sources [in Polish: Proekologiczne odnawialne źódta energii], 4th ed., WNT, Warszawa.

10. Magari S.R., Smith C.E., Schiff M., Rohr A.C. (2014), Evaluation of community response to wind turbine-related noise in Western New York State, Noise \& Health, 16, 71, 228-239.

11. Michaud D.S. (2015), Self-reported and objectively measured outcomes assessed in the Health Canada wind turbine noise and health study: results support an increase in community annoyance, Proceedings InterNoise 2015, vol. 5, pp. 3423-3440, San Francisco. 
12. Michaud D.S., Feder K., Keith S.E., VoiceSCu S.A., Marro L., Than J., Guay M., DenNing A., McGuiere D., Bower T., Lavigne E., Murray B.J., Weiss S.K., VAN Den Berg F. (2016a), Exposure to wind turbine noise: perceptual responses and reported health effects, Journal of the Acoustical Society of America, 139, 3, 1443-1454.

13. Michaud D.S., Feder K., Keith S.E., Voicescu S.A., Marro L., Than J., Guay M., DenNing A., Bower T., Villeneuve P.J., Lavigne E., Russell E., Koren G., Van den Berg F. (2016b), Self-reported and measured stress related responses associated with exposure to wind turbine noise, Journal of the Acoustical Society of America, 139, 3, 1467-1479.

14. Michaud D.S., Keith S.E., Feder K., VoiceSCU S.A., Marro L., Than J., Guay M., Bower T., Denning A., Lavigne E., Whelan C., Janssen S.A., Leroux T., VAN DEN Berg F. (2016c), Personal and situational variables associated with wind noise annoyance, Journal of the Acoustical Society of America, 139, 3, 1455-1466.

15. Minister of Economy and Labour (2005), Regulation of August 5, 2005 on safety and health at work regarding the exposure to the risks arising from noise on vibration [in Polish: Rozporzadzenie Ministra Gospodarki $i$ Pracy $z$ dn. 5 sierpnia 2005 r. w sprawie bezpieczeństwa przy pracach zwiazanych z narażeniem na hałas lub drgania mechaniczne], Journal of Laws No 157, 2005, item 1318.

16. Minister of Labour and Social Policy (2014), Regulation of June 6, 2014 on the maximum admissible concentration and intensities for agents harmful to health in the working environment [in Polish: Rozporzadzenie Ministra Pracy i Polityki Spolecznej z dnia 6 czerwca 2014 r. w sprawie najwyższych dopuszczalnych stężen $i$ natężen czynników szkodliwych dla zdrowia $w$ środowisku pracy], Journal of Laws, 2014, item 817.

17. Mroczek B., Kurpas D., Karakiewicz B. (2012), Influence of distances between places of residence and wind farms on the quality of life in nearby areas, Annals of Agricultural and Environmental Medicine, 19, 4, 692-696.

18. MroczeK B., Kurpas D., Klera M. (2013), Sustainable development and wind farms, Problemy Ekorozwoju - Problems of Sustainable Development, 8, 2, $113-122$

19. Pawlaczyk-Łuszczyńska M., Dudarewicz A., Zaborowski K., ZamoJskA-Daniszewska M., Waszkowska M. (2014), Annoyances related to wind turbine noise, Archives of Acoustics, 39, 1, 89-102.

20. Pawlas K., Pawlas N., Boroń M. (2012), Life in wind turbines vicinity, effects on health - a review [in Polish: Życie w pobliżu turbin wiatrowych, ich wplyw na zdrowie - przeglad piśmiennictwa], Medycyna Środowiskowa - Environmental Medicine, 15, 4, 150-198.

21. Pedersen E., Persson Waye K. (2004), Perception and annoyance due to wind turbine noise - a doseresponse relationship, Journal of the Acoustical Society of America, 116, 6, 3460-3470.

22. Pedersen E., Persson Waye K. (2007), Wind turbine noise, annoyance, and self-reported health and well-being in different living environments, Occupational and Environmental Medicine, 64, 7, 480-486.

23. Pedersen E., VAn den Berg F., Bakker R., Bouma J. (2009), Response to noise from modern wind farms in the Netherlands, Journal of the Acoustical Society of America, 126, 2, 634-643.

24. PN-N-01307:1994 Noise - Admissible values of noise in working environment - Measurement rules [in Polish: Hałas - Dopuszczalne wartości parametrów hałasu $w$ środowisku pracy - Wymagania dotyczace wykonywania pomiarów].

25. PN-Z-01338:2010 Acoustics - Measurement and assessment of infrasonic noise at a workplace [in Polish: Akustyka - Pomiar i ocena hałasu infradźwiękowego na stanowisku pracy].

26. Rubin G. J., Burns M., Wessely S. (2014), Possible psychological mechanisms for "wind turbine syndrome". On the windmills of your mind, Noise \& Health, 16, 69, 116-122.

27. Stryjecki M., Mielniczuk K. (2011), Guidelines in scope of forecasting environmental impact of wind farms [in Polish: Wytyczne w zakresie prognozowania oddziatywań na środowisko farm wiatrowych], Generalna Dyrekcja Ochrony Środowiska, Warszawa.

28. Vestas V80-2,0 $M W$ (n.d.), www.agroenergetyka.pl/ articles/87/pdf/V80_pol.pdf (retrieved February 14, 2017).

29. Voicescu S.A., Michaud D.S., Feder K., Marro L., Than J., Guay M., Denning A., Bower T., VAN DEN Berg F., Broner N., LaVigne E. (2016), Estimating annoyance to calculated wind turbine shadow flicker is improved when variables associated with wind turbine noise exposure are considered, Journal of the Acoustical Society of America, 139, 3, 1480-1492.

30. Wind power in Poland (2016), [in Polish: Energetyka wiatrowa $w$ Polsce], https://pl.wikipedia.org/ wiki/Energetyka_wiatrowa_w_Polsce (retrieved February 14, 2017). 